\title{
Geomorphic zoning and eogenetic karst on limestones within the supratidal environment: San Salvador, Bahamas
}

\author{
Mark H. HORWITZ* \& Tiffany M. ROBERTS \\ Department of Geology, University of South Florida, 4202 E. Fowler Ave., SCA 528 Tampa, FL USA
}

Received February 2010; accepted April 2010

Available online 27 April 2010

DOI: $10.5038 / 1937-8602.55 .1 .3$

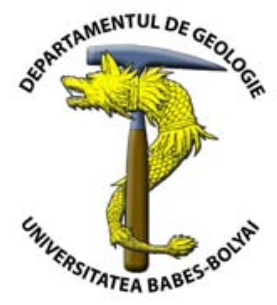

\begin{abstract}
An examination of eogenetic karst along supratidal coastal and tidally-influenced inland-lake shoreline sites was conducted on San Salvador Island, Bahamas in order to gain insight into the karst forming processes active along the land-marine interface. Based on proximity to marine aerosols and the spatial distribution patterns of surficial karst morphologies and biotic populations, four shore-parallel geomorphic zones are identified. Spatial affinities suggest haloclastic, bioerosional, and to a lesser degree, mixing dissolution/corrosion processes dominate the seaward-most region of the coastal platform, the region regularly wetted by sea spray and most deeply dissected. Further landward, where the platform remains largely free of marine aerosol, surficial karst development is more subdued and appears to be dominated by meteoric dissolution processes. The observed meso- and microkarst morphologies and associated geomorphic zoning patterns are the combined products of biological, chemical, and physical processes unique to the supratidal zone, and are largely controlled by position relative to the landmarine interface and sea level.
\end{abstract}

Keywords: geomorphic zoning, eogenetic karst, coastal erosion, bioerosion, haloclastic weathering, sea level, San Salvador, Bahamas.

\section{INTRODUCTION}

In contrast to the beach environment where morphologic change is largely attributed to the combined effects of tide, current, and wave processes yielding changes on temporal scales of hours to days, along rocky carbonate coasts morphologic change is generally a slow and gradual process, dominated by the combined effects of mechanical, biologic and chemical weathering processes (De Waele et al., 2009). Coastal karst morphologies are often distinct, characterized by jagged, pinnacled and commonly delicately etched and fretted surface morphologies, referred to as phytokarst by Folk et al. (1973). The mechanisms yielding these distinct karst morphologies appear to be in large part controlled by position relative to sea level and the land-marine interface (Moses, 2003; Taborosi et al., 2004; De Waele et al., 2009). This study examines micro- and meso-scale karst morphologies developed within supratidal exposures of eolianite and boundstone along the low-energy, rocky carbonate coast of San Salvador Island, Bahamas. On the island, Pleistocene and Holocene-age limestones are undergoing surficial meteoric diagenesis yielding eogenetic karst (Vacher and Mylroie, 2002), providing an excellent setting to examine coastal karst development.

Owing to the extensive exposures of subtidal to terrestrial carbonate rocks, accessible cave systems, and research facilities available through the Gerace Research
Center, extensive literature exists describing the karst and general geology of San Salvador Island (Carew and Mylroie, 1985; White and Curran, 1988; Carew and Mylroie, 1995; Mylroie and Carew, 2008; Onac et al., 2008). However, currently little information is available characterizing eogenetic karst development within supratidal exposures of limestone on the island.

Coastal karst morphologies may vary as a function of geology, temporal and spatial locations, and the influences of physical, biological and chemical processes (Schneider and Torunski, 1983; Duane et al., 2003; Moses, 2003; Taborosi et al., 2004; De Waele et al., 2009). Physical and textural parameters such as composition, grain sorting, and packing play a significant role in determining the extent of dissolution or erosion. For example, on San Salvador, micritic terra rossa paleosols are more resistant to erosion than the carbonate rocks they overlie. The temporal dominance of sea-level fluctuations and the spatial proximity to marine waters also strongly dominate karst formation. The effects of tides, waves, and sea-spray can be seen in the variability and extent of karst features along carbonate coastlines (Schneider and Torunski, 1983; Moses, 2003; Taborosi et al., 2004; Duane et al., 2006; De Waele et al., 2009).

Biologic processes also play a significant role in coastal karst development, especially along regions regularly wetted by waves and sea spray. The term biokarst, or bioerosion, is 
applied when the biologic activity of algae, invertebrate grazers, and inorganic mixing dissolution adds to the jagged, etched, and irregular surface topography of coastal karst (Mylroie and Carew, 2008). Depending on their location on or within the protolith, bioeroders function as epiliths, chasmoliths, or endoliths, with their distribution largely dependent on the extent and duration of moistening from marine aerosols (Kleeman, 2001), a factor largely controlled by tides, wind, and waves. Similarly, biologic communities tend to arrange themselves based on ecological tolerances against desiccation, variable ionic composition and environmental variations (i.e. temperature and humidity). In a study conducted within the arid coastal region of northern Morocco, Duane et al. (2006) suggested that active weathering and karst development on marine terraces was closely associated with endolithic and epilithic algae, attributing the undermining and deflation of the marine carbonate platform partly to algae whose filaments penetrate the rock promoting disintegration of matrix, dissolution, and biomineralization. Duane et al. (2006) further suggested that a combination of biological weathering processes, abrasion, wave action, salt spray, and wetting/drying resulted in dissolution of the rocks, with the magnitude of platform deflation decreasing with distance from the platform edge.

The interdependence of biologic communities to tolerable habitat conditions, in conjunction with spatial variations in the extent of physical and chemical weathering has led to the development of geomorphic gradients along low-lying coastal rocky exposures (Duane et al., 2003; Moses, 2003). In a study examining meso- and micro-karst morphologies within supratidal exposures of calcarenite on Lord Howe Island, Australia,

Moses (2003) recognized three distinct geomorphic zones extending landward from the platform edge. Moses (2003) attributed the morphologic variation to the combined effects of dissolution, haloclastic, and biological weathering processes. This study employs similar methods as Moses (2003), with the aim of providing new and additional insights into the physical, biologic, and chemical processes leading to the development of geomorphic zoning along the land-marine interface on San Salvador; also providing information that may be useful to coastal managers tasked with managing and maintaining coastal habitat within similar environments. Furthermore, understanding the processes leading to coastal platform deflation can lead to more effective approaches to maintaining coastal habitat, particularly when viewed within the context of rising sea level.

\section{STUDY AREA}

The Bahamian Islands form a northwest-southeast trending archipelago punctuated by low-lying exposures of Pleistocene and Holocene carbonate strata (fig. 1.). The region is considered sub-tropical with warm temperate winters and hot tropical summers. Average summer temperatures range from $21^{\circ} \mathrm{C}$ to $30^{\circ} \mathrm{C}$; while winter temperatures, influenced by the passage of cold fronts originating in the northern latitudes and traveling south, range from $16^{\circ} \mathrm{C}$ to $21^{\circ} \mathrm{C}$. Based on records for the period 1951-1970, the region receives on average $765 \mathrm{~mm}$ of rainfall annually. The islands are dominated by easterly "trade winds" with winds originating out of the eastern quadrants accounting for 63 percent of the frequency. The remaining winds are associated with either the passage of winter cold fronts yielding dominantly northerly winds or summer tropical depressions and hurricanes originating in the east-central Atlantic that tend to travel along northwest tracks.

The islands rest on a shallow carbonate platform which has been exposed and submerged intermittently during Pleistocene high and low sea-level stands (Carew and Mylroie, 1985). During the last Pleistocene interglacial (Sangamon-MIS 5e), most of the islands were submerged, yielding dominantly intertidal and subtidal carbonate facies assemblages. The subsequent glacial maxima (Wisconsin) yielded lower sea-levels exposing bank sediment, and when coupled with persistent winds, arguably may have favored eolianite deposition with fringing reef development prograding in response to the regression. Deposition of carbonate eolianite during Pleistocene intermediate to low sea-level stands has been described in similar tropical to sub-tropical settings (Fornós et al., 2009). However, current depositional models for San Salvador and the Bahamas, in general, describe mechanisms yielding both transgressive and regressive eolianites (Mylroie and Carew, 2008). In either case, primary controls on carbonate eolianite deposition require an adequate sediment supply and wind to transport the sediment.

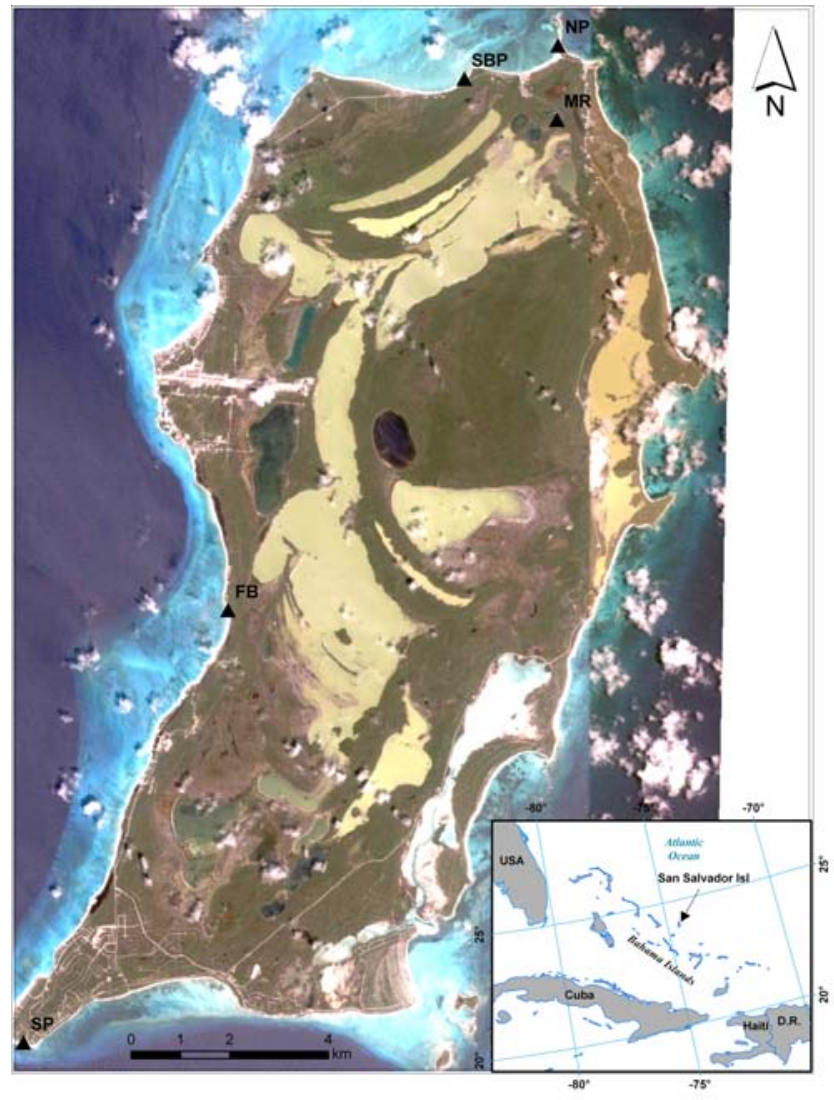

Fig. 1. Aerial image of San Salvador Island showing locations of North Point (NP), Singer Bar Point (SBP), Moon Rock Pond $(M R)$, Fernandez Bay (FB), and Sandy Point (SP) study sites.

Owing to tectonic stability of the Bahamian Islands (Mullins and Lynts, 1977), numerous studies have been conducted on San Salvador Island focused at characterizing the relationship between sea level and karst development (White and Curran, 1988; Carew and Mylroie, 1995). This study examines supratidal coastal karst features on San 
Salvador Island, a low-lying carbonate island located along the east-central portion of the Great Bahaman Bank in the northern Caribbean (Fig. 1). Exposures on San Salvador, as well as on most of the other islands in the archipelago, are dominated by variably lithified eolianite dunes with exposures of inter-tidal to subtidal deposits confined to lower elevations.

The stratigraphy of San Salvador is dominated by carbonate eolianite lithologies with lesser MIS 5e subtidal and intertidal carbonate facies (Fig. 2).

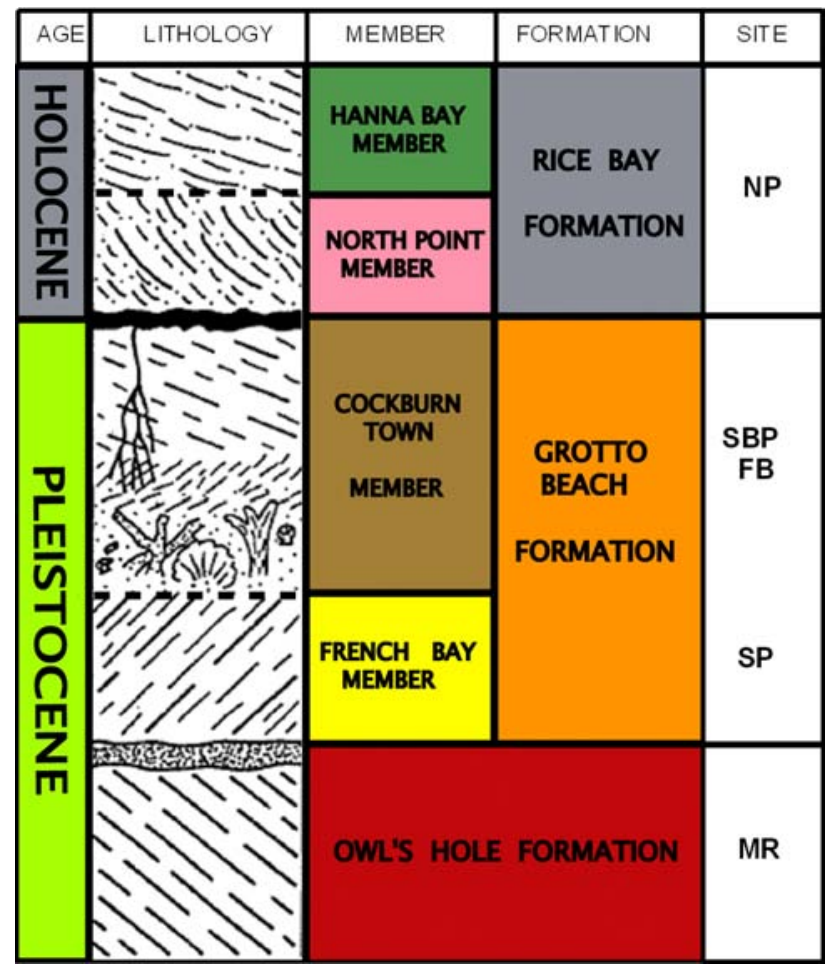

Fig. 2. Stratigraphic column for San Salvador Island (modified from Carew and Mylroie, 1995), showing field sites. The black line at the Pleistocene-Holocene boundary and stippled line lower in the section represent paleosol and proto-sol horizons, respectively.
The oldest stratigraphic unit exposed on the island is the Owl's Hole Formation, a pre-MIS 5e bioclastic eolianite. Owl's Hole is overlain by a terra rossa paleosol separating it from the overlying MIS 5e Grotto Beach Formation, which includes a lower transgressive oosparite and peloidal grainstone unit, the French Bay Member, and an upper eolianite and distinct framestone unit (fossil reef), the Cockburn Town Member. A paleosol layer overlies the Grotto Beach Formation., and marks the end of Pleistocene deposition on the island. Holocene depositional units include the early Holocene North Point Member and overlying Hanna Bay Member, both of which belong to the Rice Bay Formation. Lower Holocene lithologies are dominated by bioclastic eolianite and calcarenite facies, while the overlying Hanna Bay Member is largely comprised of intertidal facies and eolian deposits in equilibrium with the modern sea level. Beachrock found within the Hanna Bay reveal evidence of rapid cementation, exemplified by entrained cannonballs, bottle caps, and glass incorporated within the rock (Mylroie and Carew, 2008).

\section{METHODOLOGY}

In December 2008, supratidal coastal karst was examined at four sites on San Salvador, with a fifth site located along the shores of a tidally influenced interior lake (Fig. 1). The North Point (NP), Singer Bar Point (SBP), and Fernandez Bay (FB) coastal sites lie at elevations ranging from 0.5 to $1.5 \mathrm{~m}$ above mean sea level (msl). The Moon Rock Pond (MR) site is located along the northern shore of a small $\left(22,257 \mathrm{~m}^{2}\right)$, tidally influenced interior lake. While the lake surface lies at sea level, rock exposures along the lake shoreline range from sea level to elevations approximately $1.5 \mathrm{~m}$ above msl. The Sandy Point (SP) site, also located along the coast, is situated along the top of a stretch of sea cliffs, at an elevation of approximately $4 \mathrm{~m}$ above msl. Each site illustrates a range of well-developed meso-scale karst morphologies (Fig. 3).
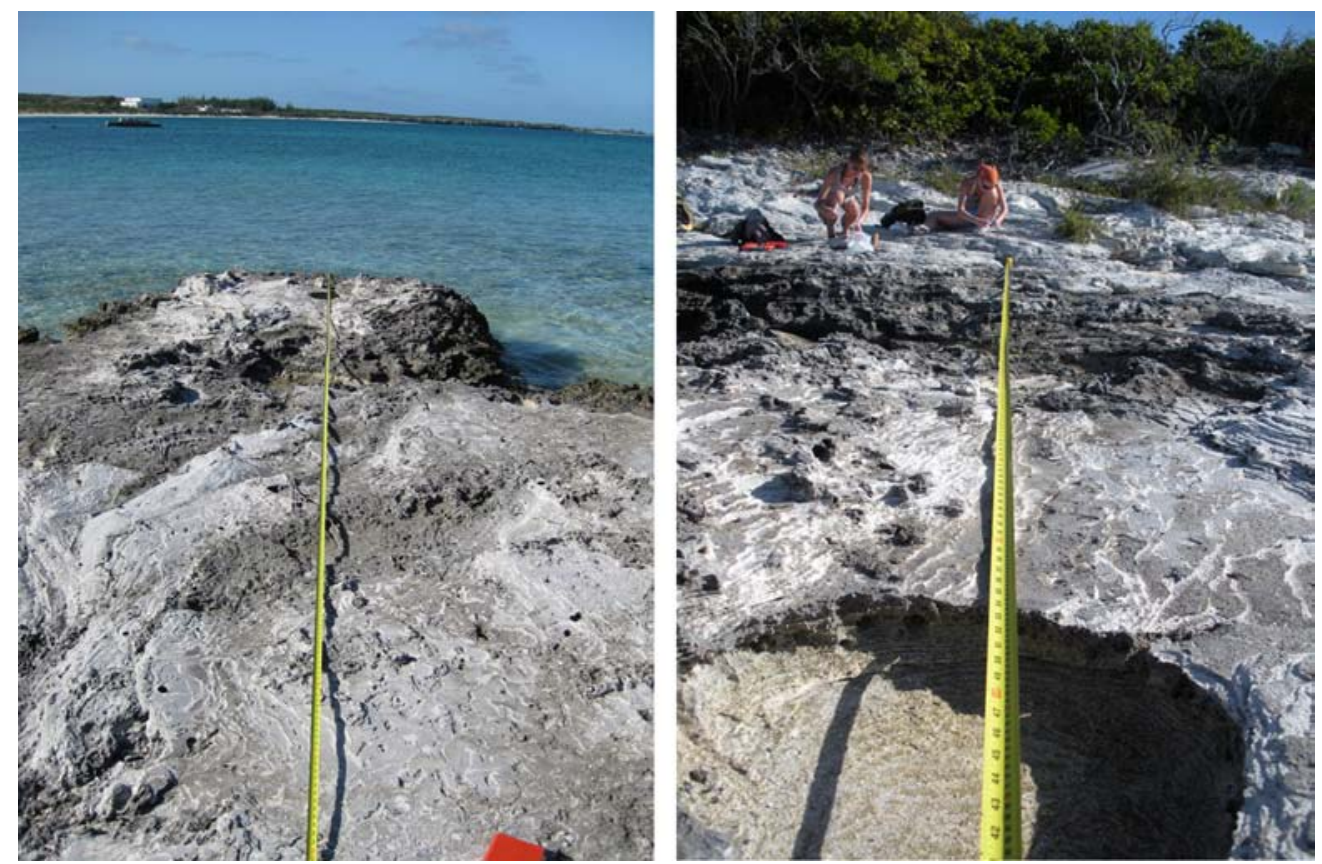

Fig. 3. Coastal karst at the NP site, showing typical transect.

The left panel shows the seaward end of the transect, and right panel shows the landward terminus.

Note large flat bottomed pan or kamenitza near the bottom of the right photo. 
Shore perpendicular transects were established at each site, and measured with a steel tape (Fig. 3). In addition, spatial data along respective transects were collected using a WAAS (Wide Area Augmentation System) enabled hand-help GPS unit, yielding horizontal position data with accuracies on the order of $\sim 2$ meters. At the SP coastal cliff site, the measured transect extended 13 meters landward from the seaward edge of the cliff, terminating at the upland vegetation line. Transects at the remaining four sites extended landward from the water's edge for distances ranging from 8 to 16 meters, with each transect terminating at the upland vegetation line. Platform slope and elevation (relative to sea level) were measured, and karst morphologies along each transect were described, photographed, and measured. Maximum dissection depths, or the maximum vertical distance from the top of the platform to the base of vertical karst features, such as pinnacles, vertical pipes, pits and kamenitzas were measured. In addition, the relative abundance of chasmolithic and epilithic grazers (gastropods) and boring algae were estimated using $0.5 \mathrm{~m}^{2}$ quadrates.

Oriented hand specimens were collected at select locations along each transect for thin section analysis. Ten thin sections were cut and mounted along planes normal to, and including, the weathered surface in order to examine microscopic scale characteristics of surface penetrating epilithic bioeroders, endolithic biota if present, and general rock characteristics.

\section{RESULTS}

\section{Platform geology}

Rock exposures at the North Point (NP) site consist of medium to thinly bedded grainstones, and exhibit finecoarse couplet layering and foreset bedding. These rocks correlate with Holocene-age bioclastic and peloidal calcarenites described by Carew and Mylroie (1995) as the North Point Member of the Rice Bay Formation. Bedding strike directions range from $\mathrm{N} 10 \mathrm{E}$ to $\mathrm{N} 90 \mathrm{E}$ with respective dip angles of $26 \mathrm{~N}$ and $10 \mathrm{~S}$. Rare thin $(<2 \mathrm{~cm})$, resistant rhyzolith bearing layers commonly form strikeparallel strips of low-relief inverted topography. The seaward edge of the platform at the NP site lies $\sim 1 \mathrm{~m}$ above $\mathrm{msl}$, and the platform dips gently seaward at 3 degrees.

Similar platform elevations and dip angles were measured at the Singer Bar Point (SBP) site. Rock exposures along this stretch of coastal platform consist of grainstone, overlain by a thin terra rossa paleosol, with paleosol exposures increasing landward. It should be noted that along "wave swept" coastal settings, the upper parts of paleosol layers can be removed by wave related mechanical erosion, therefore destroying evidence of the original thickness of the paleosol layer. Bedding at the SBP site is near horizontal, and interrupted by rare near-vertical joints oriented N 30 E. The presence of a paleosol layer suggests exposures at the SBP site belong to the upper-Pleistocene Grotto Beach Formation (Carew and Mylroie, 1995).

The coastal platform at the Fernandez Bay (FB) site dips gently seaward at 3 degrees, with the seaward edge of the platform lying at an elevation of approximately $0.5 \mathrm{~m}$ above msl. Rock exposures at the FB site include framestones and grainstones, both of which are overlain by a terra rossa paleosol layer. Framestone outcrops along the transect indicate the rock Studia UBB, Geologia, 2010, 55 (1), 17 - 27 exposures at the FB site belong to the MIS 5e Cockburn Town Member of the Grotto Beach Formation.

The Sandy Point (SP) site is located at the top of a stretch of elevated coastal cliffs along the southern tip of the island (Fig. 1), at an elevation of approximately $4 \mathrm{~m}$ above msl. The elevated platform dips seaward at approximately 10 degrees. Rock exposures consist of oosparite and peloidal grainstone which correlate with the Pleistocene-age French Bay Member of the Grotto Beach Formation (Carew and Mylroie, 1995).

The Moon Rock Pond (MR) site lies along a highly karst dissected, gently dipping (3 degree), low-lying interior lake platform $(\sim 1.4 \mathrm{~m}$ above $\mathrm{msl})$ that outcrops along the shore of Moon Rock Pond. The platform is largely comprised of bioclastic grainstone, which is overlain by a terra rossa paleosol. Measured salinity levels in the lake (35 psu) indicate a direct hydraulic connection to the open ocean, indicating the lake is tidally influenced. While it is somewhat unclear which stratigraphic unit is present at the MR site, mapping by Carew and Mylroie (1995) suggested the highly dissected platform may belong to the Cockburn Town Member of the Grotto Beach Fm. Based on platform morphology, the rocks exposed at this site may represent the erosionally truncated transgressive-phase eolianites of the French Bay Member discussed by Carew and Mylroie (1989). It should be noted that vertical relief attributed to karst development at the MR site is distinctly more intense than at the other study sites.

\section{Platform bio-cover and meso-morphology}

A broad spectrum of meso-scale eogenetic karst morphologies characterize the low-lying marine carbonate platforms exposed along the San Salvador coastline. The karst features are dominated by pitting, fretting, and solution pan (kamenitza) development. These landforms form four distinct shore-parallel zones (Fig. 4), with the most highly dissected terrain developing proximal to the seaward edge of the platform, where moisture levels and biologic activity are the greatest. Karst development decreases as a function of distance from the platform edge. These geomorphic zones are most well-developed along the low-lying coastal sites (SBP, NP, FB) where elevations generally lie at $\sim 1 \mathrm{~m}$ above $\mathrm{msl}$, and less evident at the interior MR (elevation $\sim 1.5 \mathrm{~m}$ ) and $\mathrm{SP}$ (elevation $\sim 4 \mathrm{~m}$ ) sites.

Zone 1 at the SBP, NP and FB sites extends 2 to $6 \mathrm{~m}$ inland from the seaward edge of the platform, the region most frequently wetted by sea splash and spray under normal wave conditions. This zone is highly dissected, with discrete and coalesced flat bottomed solution pans (kamenitza) separated by sharp, etched, commonly serrated, and delicately fretted alveoli, pits and pinnacles. Solution pans are most prolific within this zone, and are commonly interconnected, water filled, and have vertical to undercut walls. The pans similarly exhibit dense pitting with etched, fretted and angular/serrated alveoli forming along the vertical pit walls. With the exception of the MR site, which will be discussed later in this section, Zone 1 karst features exhibit the greatest dissection depths, reaching a maximum of $60 \mathrm{~cm}$ (Fig. 5). Algal cover (bio-cover) approaches 100 percent of the exposed rock surface (Fig. 6), which supports robust chasmolithic and epilithic grazing communities (Fig. 7). The grazers are dominated by gastropods including Cenchritis muricatus (Beaded Periwinkle), Nodilittirina ziczac (Zebra Periwinkle), and Astralium sp., which tend to congregate in pits, joints, and generally along sites where moisture retention is greatest (Fig. 8). 


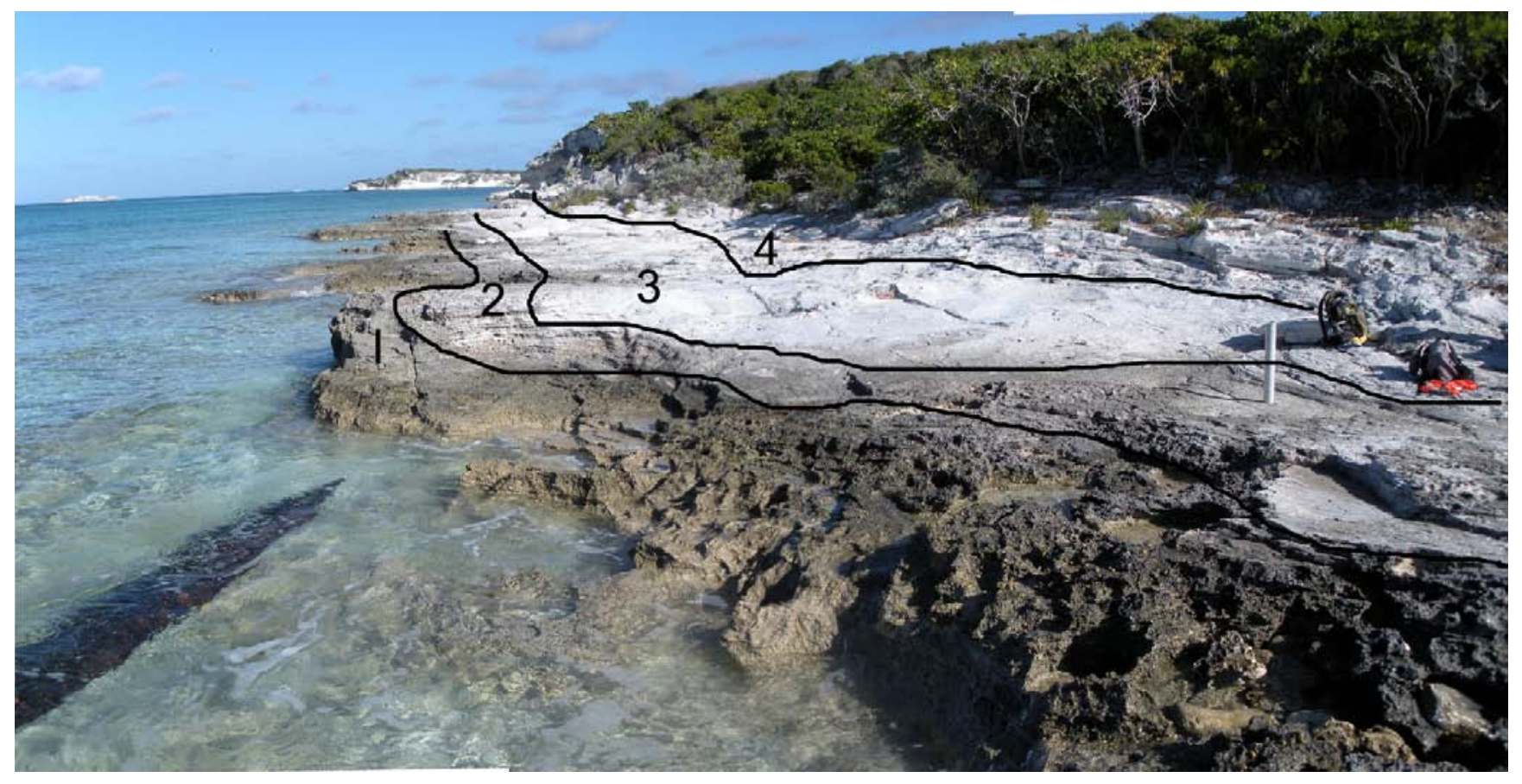

Fig. 4. Photograph of NP site showing zones of eogenetic karst characterizing the low-lying platforms along the San Salvador coast.

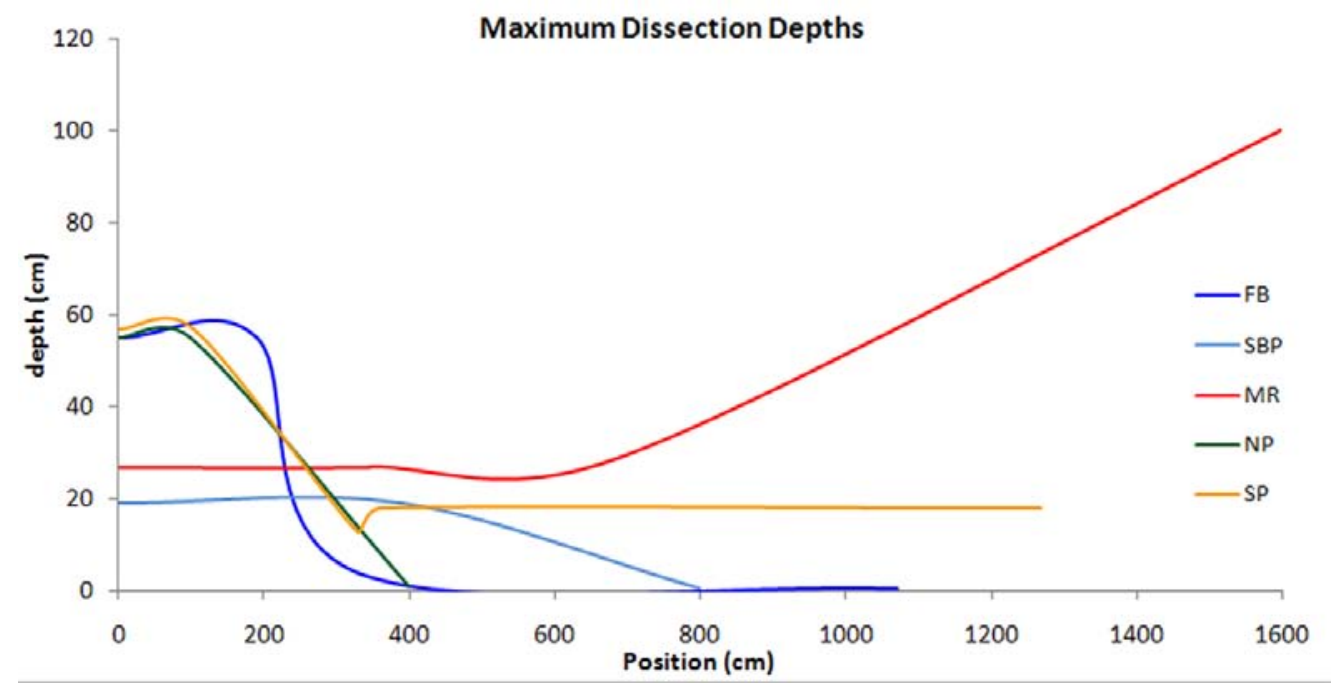

Fig. 5. Maximum dissection depths of karst as a function of distance from the seaward edge of the platform.

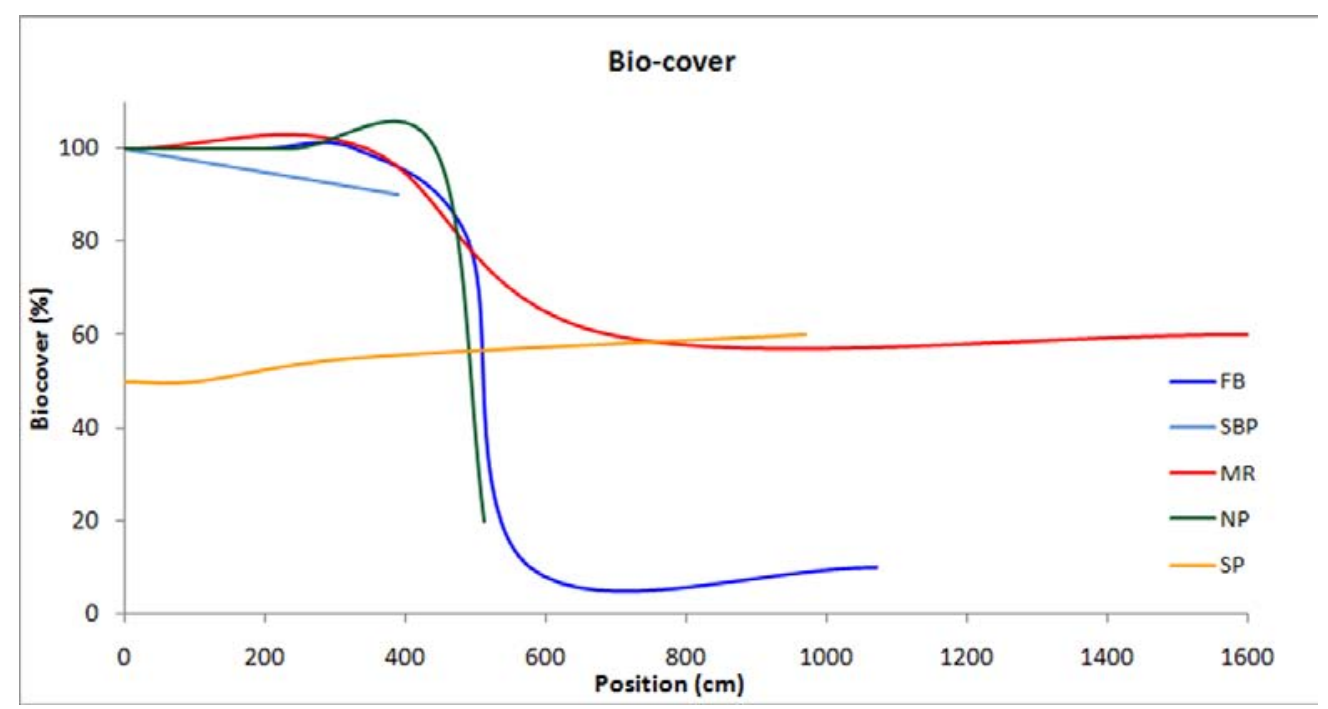

Fig. 6. Estimated percent of rock exposure covered by algae and lichens, as a function of distance from platform edge.

Studia UBB, Geologia, 2010, 55 (1), 17 - 27 
Zone 2 extends several meters inland beyond Zone 1 . The region is intermittently wetted by sea spray and splash, especially during storm-induced elevated wave conditions and/or spring tides. Karst development is similar to that seen in Zone 1; however, fretting along pit and alveoli walls is smoother and lacks the sharp, delicate fretting and serrations seen further seaward. Solution pans or kamenitza are shallower, generally discrete, and contain little to no water. Maximum dissection depths approach $20 \mathrm{~cm}$. Algae and lichen cover (bio-cover) approaches 70 percent of the exposed rock surface (Fig. 6), with epilithic grazing populations (Fig. 8) present in common to minor amounts (Fig. 7).

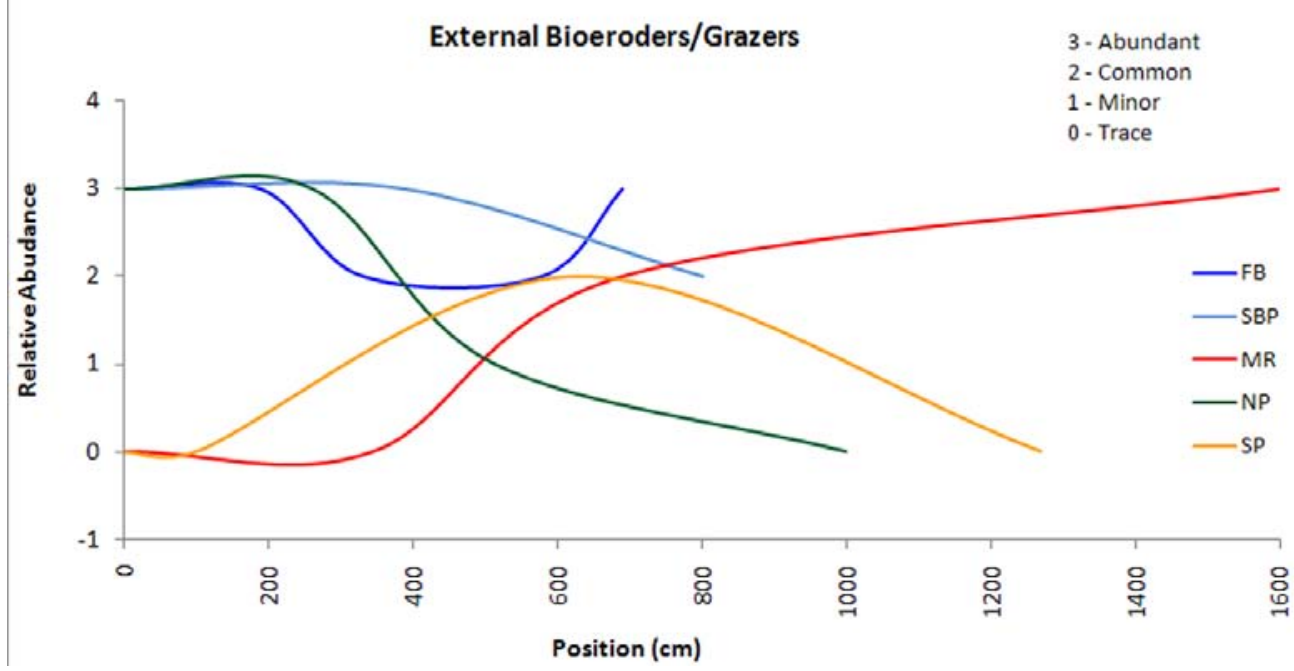

Fig. 7. Relative abundance of epilithic bioeroders (dominantly gastropods) as a function of distance from platform edge.
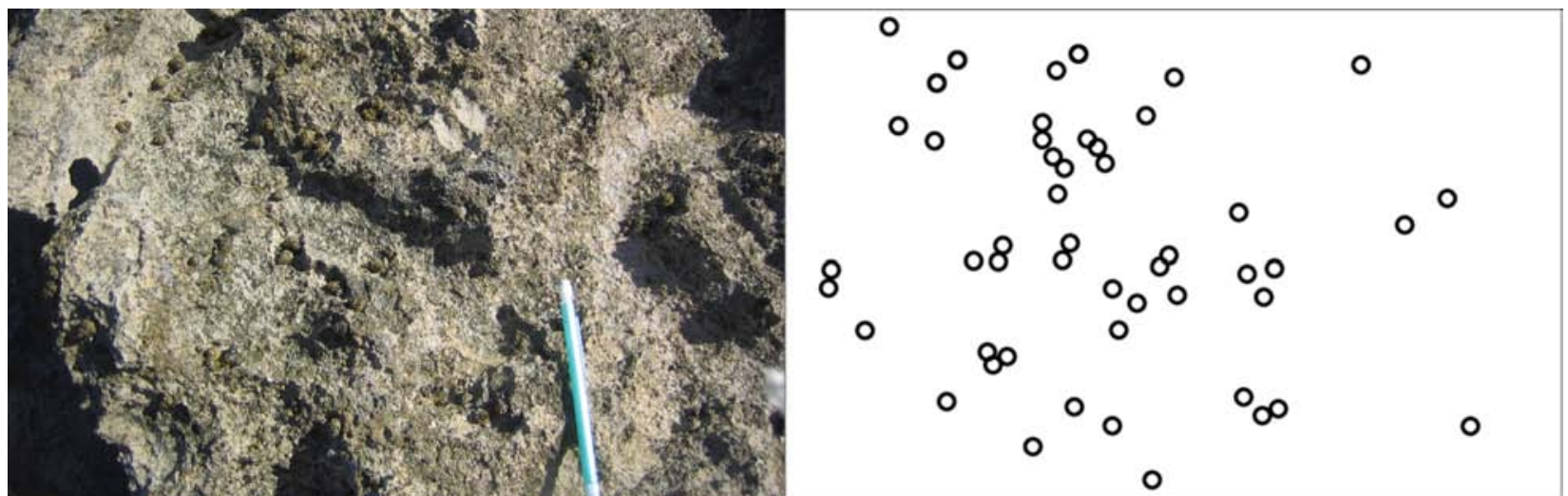

Fig. 8. Typical distribution of epilithic and chasmolithic grazing biota, here dominated by Cenchritis muricatus (Beaded Periwinkle). Note that individuals tend to congregate in shadowed regions, likely due to increased moisture content.

The right panel highlights the distribution of Cenchritis muricatus (Beaded Periwinkle) shown in the left photo.

The region represented in the images is $0.18 \mathrm{~m}^{2}$, which based on the 50 individuals present, equates to 350 grazing individuals per $\mathrm{m}^{2}$.

Zone 3 extends from approximately 8 to $12 \mathrm{~m}$ inland from the seaward edge of the platform. While it is likely that this region receives some level of sea spray during spring tidal cycles and storm events, under normal wave conditions this section of the platform generally remains free of marine aerosols. Thin $(<2 \mathrm{~cm})$, resistant rhyzolith bearing eolianite layers commonly form strike-parallel strips of low-relief inverted topography. Otherwise, the platform surface is generally smooth and rounded, containing low density, low relief $(<1 \mathrm{~cm})$ pits. Pit walls are smooth and rounded, lacking the distinct fretting and alveolar morphologies characterizing the two seaward zones. Kamenitza are rare, and bio-cover approaches 15 percent or less of the exposed rock surface, accounting for an overall lack of epilithic grazing fauna.

Zone 4 extends from approximately $12 \mathrm{~m}$ inland to the upland vegetation line. This zone lies well beyond the influence of splash and sea spray, except perhaps under the most extreme storm-elevated wave conditions. The platform surface is smooth, lacks pitting, and translates landward to a Studia UBB, Geologia, 2010, 55 (1), 17 - 27 more angular, stair-stepped surface. Algal cover and epilithic grazers are absent. Rock deflation this far landward appears to be dominated by dissolution mechanisms similar to those acting on upland and interior limestone exposures.

While it would be reasonable to characterize the overall karst landscape at the MR site as typical coastal eogenetic karst, the platform, which dips 3 degrees along this interior lakeshore site exhibits substantially greater dissection by vertical dissolution features than observed at the other coastal sites examined in this study (Fig. 9). Similarly, geomorphic zoning patterns among the karst morphologies are less distinct at MR than compared to other open-marine sites suggesting a strong influence by mixing dissolution associated with tidal forcing. Kamenitza are largely absent and vertical relief is dominated by high density small diameter $(9-100 \mathrm{~cm})$ vertical pipes. These pipes can extend to depths of a meter below the platform surface (Fig. 5) and in most cases remain partially water-filled due to a direct hydraulic connection with the lake. The average dissection depth along the $16 \mathrm{~m}$ transect is 52 $\mathrm{cm}$, in contrast to the low-lying coastal sites where dissection 
depths $8 \mathrm{~m}$ from the platform edge approach zero. Extending $2 \mathrm{~m}$ landward from the water's edge, the platform is highly dissected and pinnacled with finely etched and fretted alveoli and pits. Further landward, while still highly dissected by vertical solution pipes, surface pitting, alveoli, pinnacles, and pit walls become distinctly smoother and variably etched and

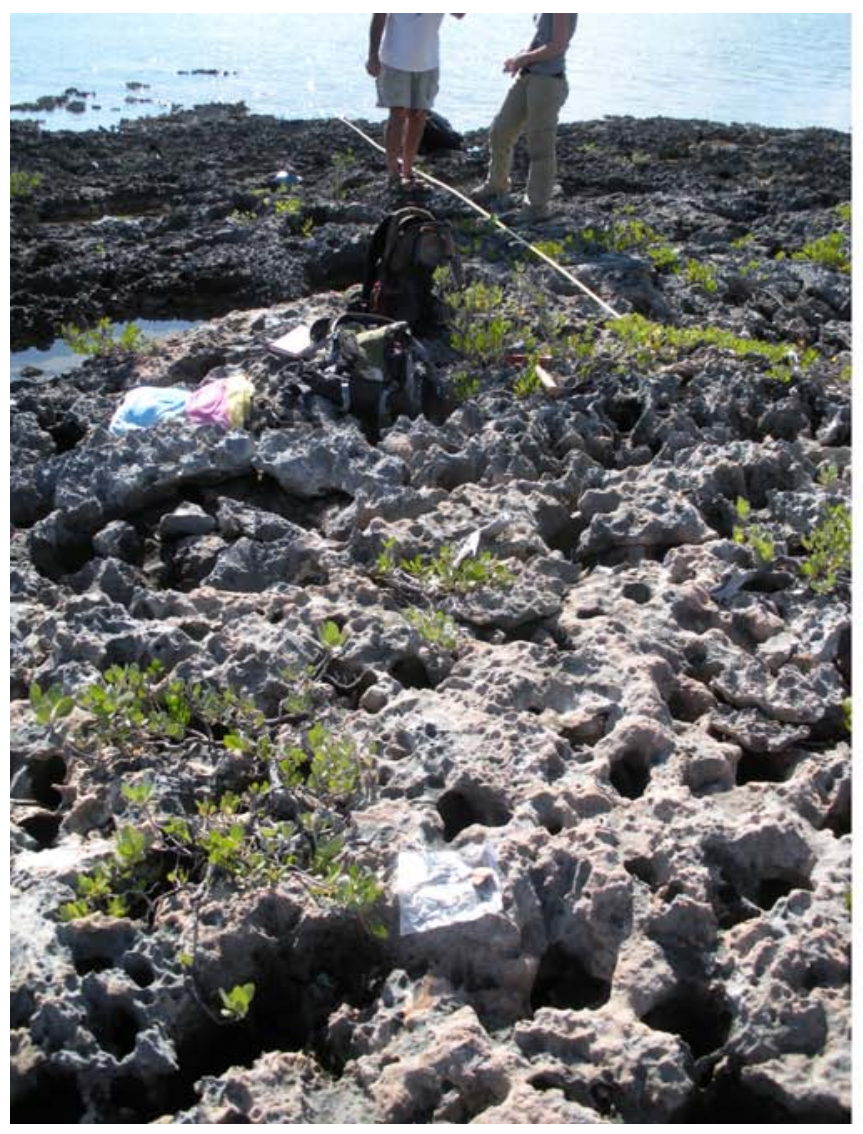

fretted. Extending landward $4 \mathrm{~m}$ from the water's edge, algal cover approaches 100 percent, declining to 50 percent further landward along the remainder of the transect. Epilithic grazing communities are less common along the shorewardmost $4 \mathrm{~m}$ of the transect, and increase in abundance landward of that position (Fig. 7).

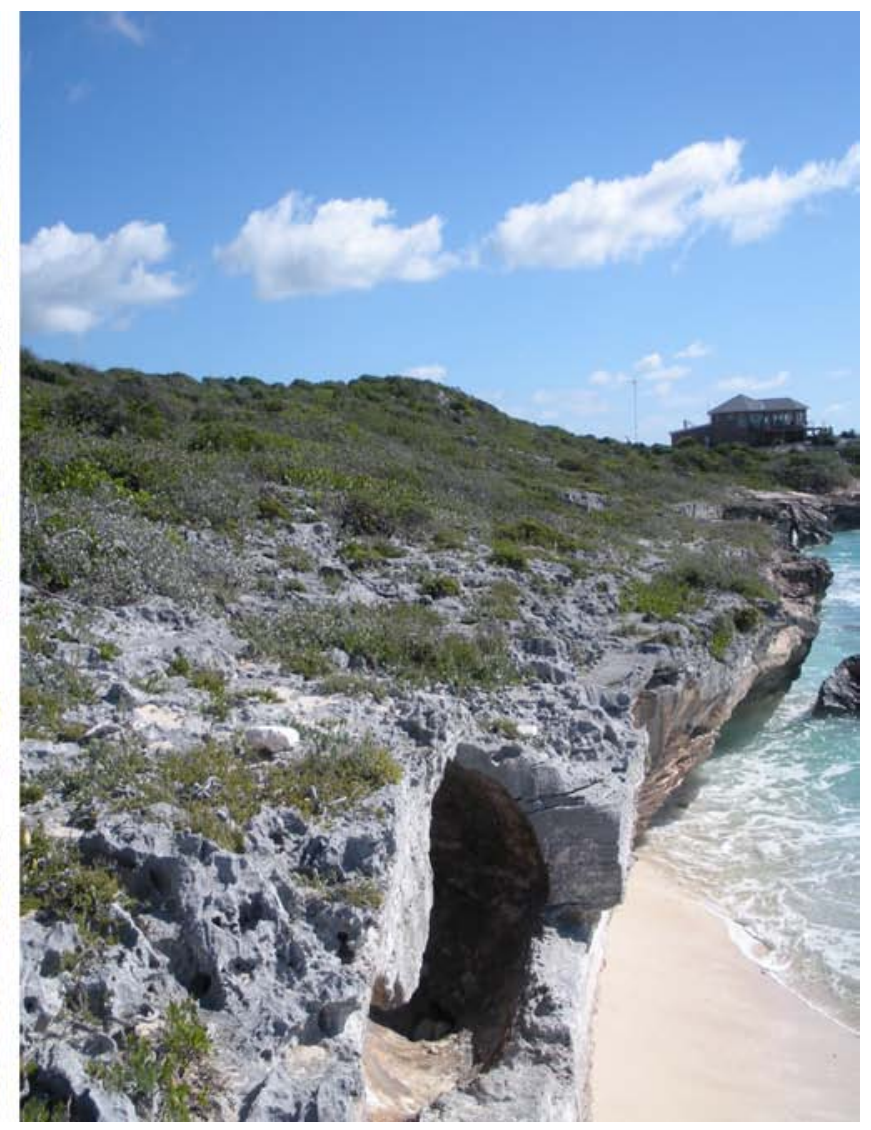

Fig. 9. Left photo shows eogenetic karst development along shore of Moon Rock Pond (MR site). Right panel shows coastal cliffs and elevated platform characterizing the SP site.

In contrast to the lower elevation sites $(<1.5 \mathrm{~m}$ above sea level), where a significant portion of the supratidal platform is regularly wetted by splashing and sea spray and the platform dips at low angles $\left(3^{\circ}\right)$ seaward, the SP site lies along the top of a stretch of coastal cliffs at an elevation of approximately $4 \mathrm{~m}$ above msl. The platform dips 11 degrees seaward, and lies well beyond the influence of splash and spray (Fig. 7), except perhaps during extreme storm events. Wetting of the platform along this stretch of coast therefore relies largely on precipitation events and to a lesser degree, episodic storm related sea spray. Zone 1 karst morphologies in the form of etching and delicately fretted pits, pinnacles, and alveoli are clearly evident extending approximately $2 \mathrm{~m}$ landward from the cliff face. Further landward, extending to the vegetation line, the platform remains moderately dissected with an average dissection depth of $26 \mathrm{~cm}$. Solution pans, pits and alveoli walls are variably fretted but smooth and consistent with Zone 2 type karst morphologies. Bio-cover approaches 50 percent uniformly over the length of the transect, which supports a limited epilithic grazing population (Fig. 6).

\section{Thin section analysis}

Ten thin sections were examined in order to analyze the microscopic characteristics of the coastal karst (Figs. 10-12). A thin epilithic algal layer was visible in all the samples, penetrating to a maximum depth of $1 \mathrm{~mm}$ from the weathered surface. Algal penetration into the rock is likely controlled by light compensation depths (Kleeman, 2001). The algal layer is commonly zoned with an outer zone penetrating $200 \mu \mathrm{m}-500 \mu \mathrm{m}$ into the rock from the weathered surface, and characterized by a dense felted maze of algal filaments locally stained greenish due to the presence of chlorophyll pigment. The inner zone is comprised of discrete filaments, that penetrate matrix cement and, to a lesser degree grains, to a maximum depth of $1000 \mu \mathrm{m}$ (Figs. 9 and 10).

Eolianites from the coastal SBP and NP sites tend to have a high primary intergranular porosity, and are weakly to moderately cemented with meniscus cement, in contrast to the well-cemented (dominantly isopachous), low intergranular porosity observed in eolianite samples from the SP, MR and FB sites (Fig. 9). In addition, ooids, pelloids and biogenic grains within the eolianites from the SP, MR, and FB sites are commonly leached, deformed, and recrystallized often exhibiting reddish stained (iron oxide) concentric micritic selvadges (Fig. 11).

Based on the ages of eolianite outcrops on San Salvador reported by Mylroie and Carew (2008), the degree of cementation appears to be directly proportional to the age of the rock. Pleistocene eolianites from the MR, FB, and SP sites tend to be more thoroughly cemented, while Holocene eolianites from the NP and SBP sites tend to be poorly cemented.

Studia UBB, Geologia, 2010, 55 (1), 17 - 27 

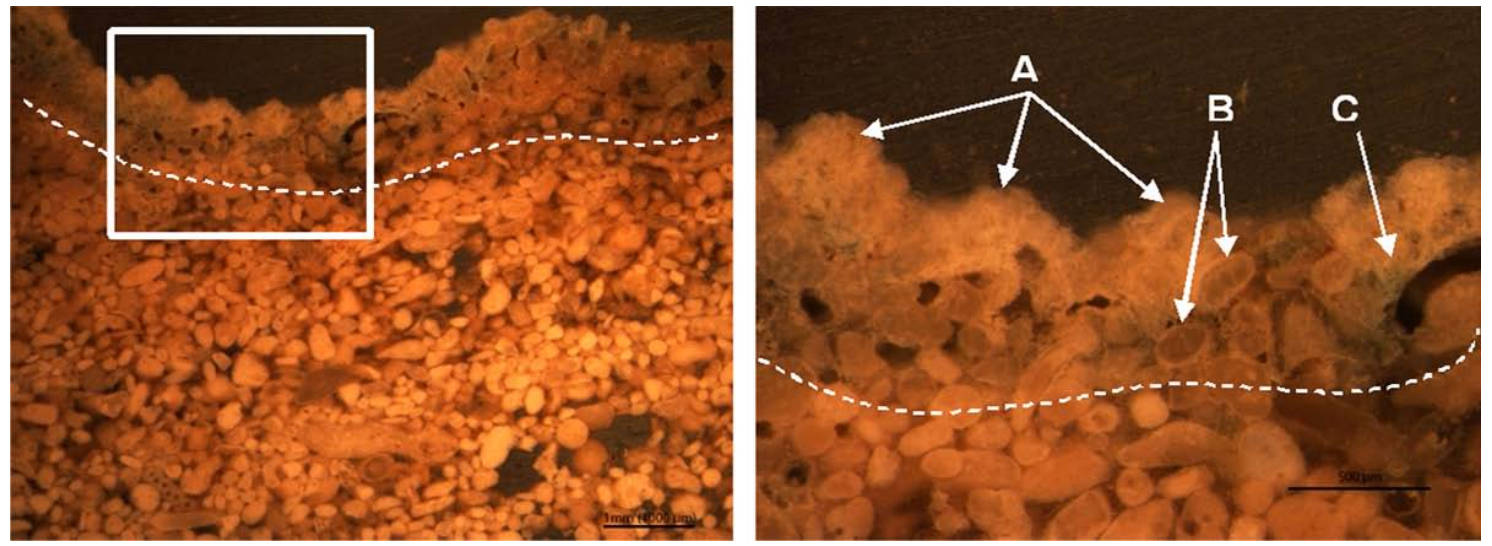

Fig. 10. Thin sections showing weathered surface of eolianite from Zone 1 at the NP site.

The weathered edge exhibits micro-pinnacles (A), and a $1 \mathrm{~mm}$ thick epilithic algal layer (white dashed lines). In the right image, algal filaments are visible as white needles penetrating matrix cement, and to a lesser degree grains. Grains closest to the weathered surface often exhibit micritic selvedges $(B)$. The greenish patches $(C)$ are attributed to chlorophyll pigment. Note the low degree of cementation within the rock. The white box in the left panel represents the extent of the image shown in the right panel. The scale bar on the left panel is $1000 \mu \mathrm{m}$, and $500 \mu \mathrm{m}$ on the right panel.
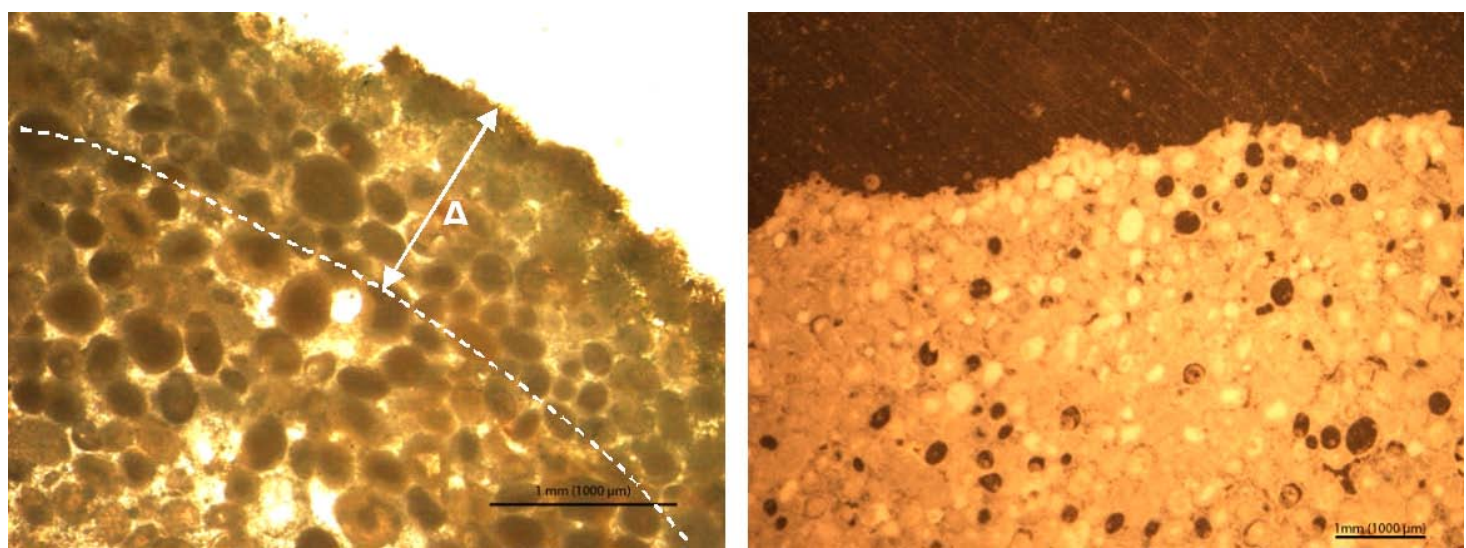

Fig. 11. Thin sections showing weathered surface of eolianite from the SP site.

The weathered edge in the left photo shows a $1 \mathrm{~mm}$ thick epilithic algal layer (A) and subtle greenish staining attributed to chlorophyll pigment, which penetrates into the rock approximately $500 \mu \mathrm{m}$. The right photo shows significantly higher levels of cementation than observed in younger Holocene-age eolianites from the NP and SBP sites. Scale bars in each photo represent 1000 $\mu m$.
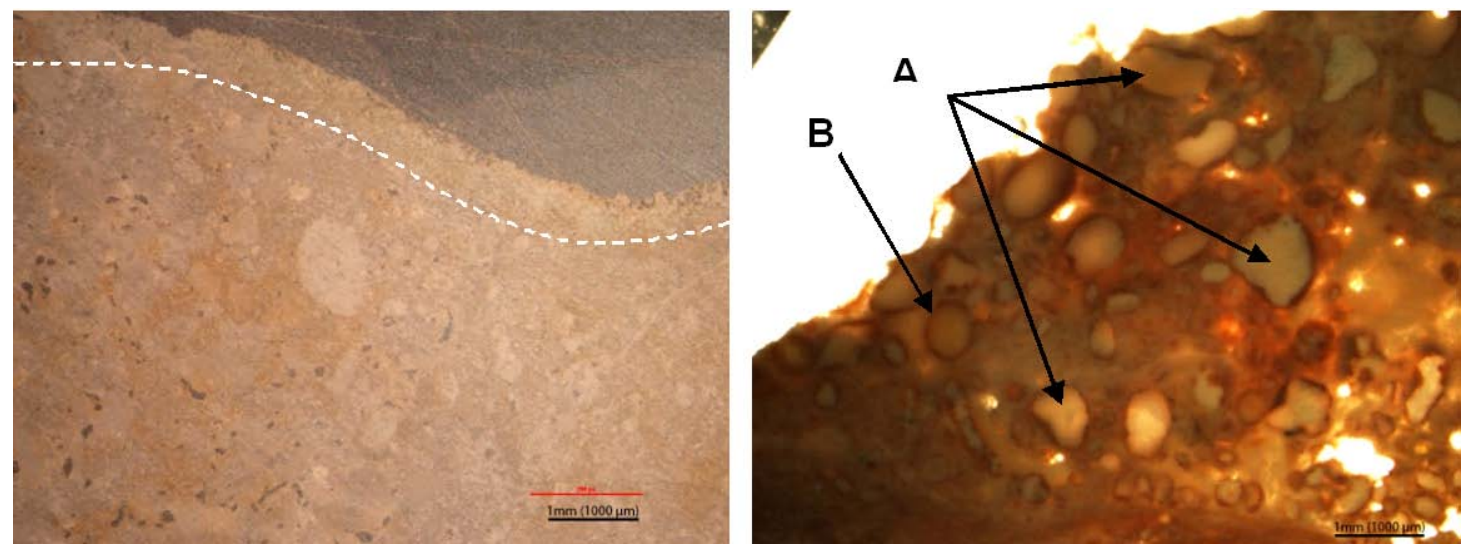

Fig. 12. Thin sections of weathered surface of eolianite from the MR site. The photo on the left shows an epilithic algal layer penetrating $600-700 \mu \mathrm{m}$ into the rock (white dashed line), and relatively dense cementation. The dense isopachous cementation is clearly visible in the right photo, along with deformed grains (A) and iron oxide-rich dark reddish micritic grain coatings (B). Scale bars represent $1000 \mu \mathrm{m}$ in each photo.

\section{DISCUSSION}

Based on karst morphologies in conjunction with the spatial distribution of biologic organisms, distinct and consistent geomorphic zoning patterns are recognized along supratidal coastal platform exposures on San Salvador Studia UBB, Geologia, 2010, 55 (1), 17 - 27
Island. Four shore parallel zones are recognized and illustrate micro and meso-scale textures and morphologies consistent with varying degrees and combinations of haloclastic processes, bioerosion, and dissolution. This geomorphic gradient is best developed along the low-lying NP, SBP, and FB coastal platform sites, and less distinct at the SP and MR sites where correlation is limited to the 
region lying within the influence of salt spray and splash. Overall, variations in karst morphologies appear to be largely controlled by position relative to the land-marine interface and sea level.

Zone 1, the seaward-most zone, extends inland from the platform edge 2 to $6 \mathrm{~m}$, and lies within reach of regular (daily) wave splash and sea spray. With the exception of the Sandy Point (SP) site, where the platform is elevated and sea spray likely only reaches the platform during extreme storm events, this zone is well represented at all the other study sites. Platform dissection is greatest within this zone, with a maximum dissection depth of $60 \mathrm{~cm}$. Water-filled kamenitza, pits and pinnacles are most prolific within this zone; however, the most distinct karst morphologies consist of etched, fretted, sharp angular alveoli, pit walls, and pinnacles. Biologic activity is greatest within this zone. Algal cover of exposed rock surfaces approaches 100 percent and supports large and robust populations of epilithic and chasmolithic grazing species (Fig. 8). A number of hypotheses have been advanced over the years proposing explanations for the formation of finely etched and fretted alveolar textures. Folk et al. (1973) suggested that the delicate coastal weathering textures characterizing phytokarst were largely the product of bio-erosional processes. Other studies have stressed the importance of haloclastic processes, showing that delicately etched textures characteristically develop in rocks lying within reach of frequent sea spray, and are absent within compositionally identical rocks lying further inland beyond the reach of marine aerosols (Hume, 1925; Cailleux, 1953; Bourcart, 1957). Mustoe (1982) found concentrations of soluble $\mathrm{Na}^{+}$in supratidal rocks lying within the reach of sea spray to be an order of magnitude higher than those found in compositionally similar rocks exposed further landward beyond the reach of salt spray. In the same study, fresh disaggregated feldspar grains were commonly observed within mirco-pits and alveolar cavities, suggesting that the delicate weathering textures result from physical disaggregation rather than chemical alteration. While it is reasonably clear that haloclastic processes play a key role in karst formation within this zone, it is likely these processes are temporally variable, due to influences by tides, waves, and meteorological conditions.

In addition to haloclastic processes, biological processes within Zone 1 further act upon the rock to exacerbate grain disaggregation. Bioerosion occurs through a combination of disaggregation from breakdown of matrix cement and grains by epilithic/endolithic algal filaments (Figs 9 and 10) and biologic abrasion resulting from the action of epilithic and chasmolithic grazing communities (Torunski, 1979). These two moisture dependent bio-erosional mechanisms act in a quasi-symbiotic manner, in that without algal cover, it is unlikely epilithic grazing communities would flourish. Algal penetration, limited by light compensation depth, increases as the grazing biota abrade and lower the rock surface. While the above processes appear to play closely related key roles in nearshore karst development, dissolution and attack by chemically aggressive waters and mixing dissolution likely contributes to karst development, particularly within closed basin features capable of retaining meteoric water. The magnitude and style of karst development within the most biologically, chemically, and physically aggressive environments (Zone 1) are comparable at all sites. Therefore, it appears that within granular carbonate rocks, composition plays little role, if any, in governing karst development in the aggressive coastal environments along San Salvador.

Zone 2 extends several meters inland beyond Zone 1 . This region is intermittently wetted by sea spray and splash, especially during storm-induced elevated wave conditions and possibly spring tides. Maximum dissection depths approach $20 \mathrm{~cm}$. Owing to the increased distance from the platform edge, overall moisture levels within this zone are reduced, accounting for a reduction in algal cover to 70 percent of exposed rock surfaces, and a reduced epilithic grazing population. Karst development, while similar to that seen in Zone 1, illustrates a marked reduction in the density and size of pits, kamenitza, and solution pans. Pinnacles are rare, and while still fretted to varying degrees, alveoli and pit walls are generally smooth and rounded lacking the sharp, delicate etching seen further seaward. This reduction in angularity is attributed to reduced contributions by haloclastic and bioerosional processes.

Zone 3 extends from approximately $8 \mathrm{~m}$ to $12 \mathrm{~m}$ inland from the seaward edge of the platform. This section of the platform normally lies beyond the reach of sea spray splash except during spring tidal cycles coinciding with storm events. The lack of moisture accounts for the limited $(\leq 15$ $\%)$ algal cover, sparse distribution of epilithic grazers, and overall paucity of bio-erosional features. Karst development appears to be dominated by meteoric dissolution processes resulting in slow surficial disaggregation, yielding a smooth weathered surface. Although limited in its overall contribution, bioerosion likely occurs in topographically low areas or zones prone to retaining moisture.

Zone 4 extends from approximately $12 \mathrm{~m}$ landward from the platform edge to the upland vegetation line, and lies well beyond the influence of sea spray and splash except during the most severe storm-induced wave conditions. Biologic activity within this zone is nominal. Platform slope increases rapidly in the landward direction. Karst development appears to be dominated by meteoric dissolutional processes, and exhibits little evidence of weathering that can be attributed to coastal karst processes.

Geomorphic gradients along low-lying wave cut coastal platforms on San Salvador are strongly influenced by moisture levels and, therefore, position relative to the platform edge and sea level. Consequently, spatial affinities strongly suggest haloclastic and bioerosional processes dominate Zones 1 and 2, the regions regularly wetted by sea spray. This can also be construed to include essentially any rock periodically exposed to salt splash and spray. This is true for elevated coastal cliffs, as well as the shoreline of a saline interior lake, assuming the lake has a large enough fetch to allow some level of waves to develop under prevailing wind conditions, resulting in a saline aerosol. It should be noted however, that landward of Zone 1, geomorphic zoning at sites other than along low-lying platforms is poorly developed and karst appears to be dominated by meteoric dissolution in conjunction with local processes. At the SP site, etched and fretted karst morphologies suggestive of haloclastic erosional processes extended $1 \mathrm{~m}$ landward from the cliff face. However beyond that point, karst morphologies appear to be dominated by meteoric dissolution.

In the case of the MR site, although a narrow Zone 1 exists that extends $2 \mathrm{~m}$ landward from the shoreline, both haloclastic and bioerosional karst development appear to 
overprint on what was already an intensely dissected platform surface dominated by small diameter (generally < $0.5 \mathrm{~m}$ ) vertical solution pipes in places reaching $1 \mathrm{~m}$ in depth. While the overall morphology of the karst closely resembles to the smooth but jagged pinnacles and pits characterizing Zone 1 along the active low-lying coastal platform sites, the density, lateral and vertical extent of the karst features suggest karst development at this location is much older or is the product of more aggressive chemical and biological attack. Mylroie and Carew (2008) attribute this unusually intense karst development to aggressive mixing dissolution between meteoric and saline lake water. Additionally, given the MR sites inland position, mechanical erosion resulting from wave attack would be limited, allowing for greater preservation of karst, explaining the anomalously intense karst dissection observed along the lake shoreline.

\section{CONCLUSION}

An examination of eogenetic coastal karst along San Salvador Island was conducted at multiple supratidal coastal and inland lakeshore sites to gain insight into the karst forming processes active along the land-marine interface. Based on proximity to marine aerosols, and the spatial distribution patterns of karst morphologies and biotic populations, four shore parallel geomorphic zones were identified. The geomorphic zones and suggested karst forming mechanisms are shown in Fig. 13. Similar geomorphic gradients have been reported at other coastal locations worldwide (Spencer and Viles, 2002; Moses, 2003; De Waele et al., 2009), suggesting that coastal karst development is the product of combined physical, chemical, and biologic processes unique to marine coastal environments.

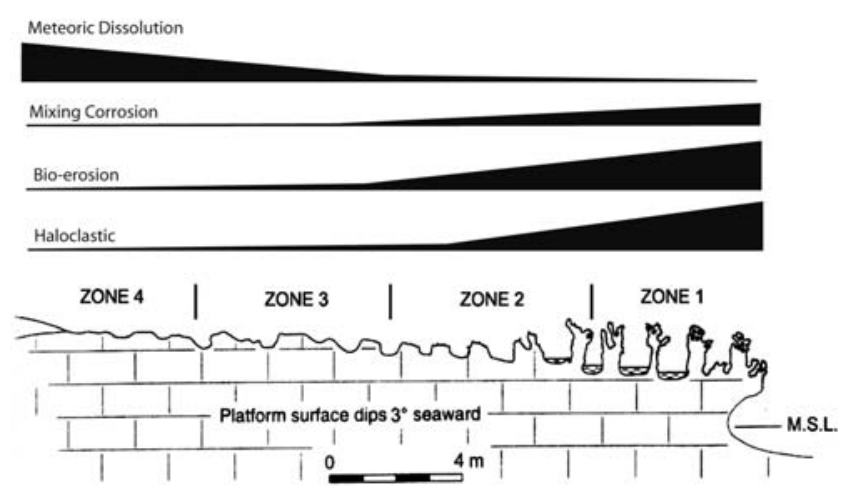

Fig. 13. Cartoon showing geomorphic zones identified along low lying coastal platform sites on San Salvador Island (modified from Moses, 2003), and spatial organization of respective karst forming processes. The thickness of the horizontal black bars in the upper panels is directly proportional to the importance of the process within the corresponding geomorphic zones.

Spatial affinities strongly suggest haloclastic and bioerosional processes dominate Zones 1 and 2, the regions regularly wetted by sea spray. These processes yield a distinct suite of karst features that include the delicately etched and fretted pits, pinnacles, pans and kamenitzas. Both processes rely heavily on retained moisture content and, therefore, are most active where coastal rock exposures are regularly wetted by marine aerosols. Karst processes within Zone 1 are rather aggressive and appear to work independent of rock formations present on San Salvador. Studia UBB, Geologia, 2010, 55 (1), 17 - 27
Rates of erosion attributed to endolithic and epilithic grazing biota have been estimated to range from 0.07 to $1.1 \mathrm{~mm}$ per year (Schneider and Torunski, 1983). This seems plausible given the intense level of dissection characterizing this seaward most supratidal zone. Landward of Zone 2, where the region remains largely free of sea spray, karst development in Zone 3 is subdued, and appears to be dominated by meteoric dissolution processes. This also appears to be the case for Zone 4 where karst development appears to be less related to coastal processes and largely the product of meteoric dissolution that can account for dissolutional lowering of the platform at rates of $65-140 \mathrm{~mm}$ $\mathrm{ka}^{-1}$ (Whitaker and Smart, 2007). While mechanical erosion resulting from episodic attack by storm-elevated waves is not considered a primary karst forming process, this mechanism certainly contributes to platform lowering, and likely serves to periodically renew the surface of coastal rock exposures promoting subsequent karst development.

The eogenetic karst morphologies and the geomorphic zoning patterns identified, particularly at the low-lying coastal platform sites, are distinctly unique to the supratidal region of the marine-land interface in the tropical to subtropical climate of San Salvador Island. Given that karst development within the shore-proximal zone appears to develop regardless of carbonate lithology, identification of similar karst morphologies and geomorphic zoning patterns within the geologic record may provide some insight into past sea levels, particularly within late-Cenozoic rocks. While this study provides new insights into the karst processes acting on coastal carbonate rock exposures, future efforts should be directed at quantifying rates of platform deflation, which might be considered useful to coastal managers when mitigating anthropogenic issues along regions of active eogenetic coastal karst development.

Acknowledgments. We would like to thank Dr. T. Rothfus and the Gerace Research Center, San Salvador Island, Bahamas for logistical support provided during field data collection. In addition, this manuscript was greatly improved by reviews from J. De Waele, and an anonymous reviewer. We would also like to thank colleague T. Beck for her help in the field.

\section{R E F E R E N C E S}

Bourcart, J. 1957, L'erosion des continents. Ed. Armand Colin, Paris, $216 \mathrm{p}$.

Cailleux, A. 1953, Taffonis et erosion alveolaire. Cahier Geologie de Thoiry, 16-17: 125-140.

Cardell, C., Delalieux, K., Roumpopoulos, K., Auger, F. \& Van Grieken, R. 2003, Salt-induced decay in calcareous stone monuments and buildings in a marine environment in SW France. Construction Building Materials, 17: 165-179.

Carew, J.L., Mylroie, J.E. 1985, Pleistocene and Holocene stratigraphy of San Salvador Island, Bahamas, with reference to marine and terrestrial lithofacies at French Bay. In: Guidebook for Geological Society of America, Orlando Annual Meeting, Field Trip \#2 (Curran, H.A., Ed.), Fort Lauderdale, Florida, Bahamian Field Station, 11-61.

Carew, J.L., Mylroie, J.E. 1989, Stratigraphy, depositional history, and karst of San Salvador Island, Bahamas. In: Pleistocene and Holocene carbonate environments on 
San Salvador Island, Bahamas (Curran, H.A., Ed.), Field trip guidebook T175, 28 $8^{\text {th }}$ International Geological Congress, American Geophysical Union, Washington, D.C. 7-15.

Carew, J.L., Mylroie, J.E. 1995, A stratigraphic and depositional model for the Bahama Islands. In: Geological Society of America Special paper 300, Terrestrial and shallow marine geology of the Bahamas and Bermuda (Curran, H.A., White, B., Eds.), 5-31.

Carew, J.L., Mylroie, J.E. 1997, Geology of the Bahamas. In: Geology and hydrogeology of carbonate islands (Vacher, H.L., Quinn, T.M., Eds.), Elsevier, 91-139.

De Waele, J., Mucedda, M. \& Montanaro, L. 2009, Morphology and origin of coastal karst landforms in Miocene and Quaternary carbonate rocks along the central-western coastal of Sardinia (Italy). Geomorphology, 106 (1-2): 26-34.

Duane, M.J., Al-Mishwat, A.T. \& Rafique, M. 2003, Weathering and biokarst development on marine terraces, northwest Morocco. Earth Surface Processes and Landforms, 28: 1439-1449.

Folk, R.L., Roberts, H.H. \& Moore, C.H. 1973, Black phytokarst from Hell, Cayman Islands, British West Indies. Geological Society of America Bulletin, 84: 2351-2360.

Fornós, J.J., Clemmensen, L.B., Gomez-Pujol, L. \& Murray, A.S. 2009, Late Pleistocene carbonate aeolianites on Mallorca, Western Mediterranean: a luminescence chronology. Quaternary Science Reviews, 28: 2697-2709.

Hume, W.F. 1925, Geology of Egypt, Surface Features. Government Press, Cairo, p. 214-216.

Kleemann, K. 2001, Marine Bioerosion. University of Vienna Lecture: 21/08/01, http://www.sbg.ac.at/ipk/ avstudio/pierofun/transcript/bioer.s.pdf

Moses, C.A. 2003, Observations on coastal biokarst, Hells Gate, Lord Howe Island, Australia. Zeitschrift für Geomorphologie, 47 (1): 83-100.
Mullins, H.T., Lynts, G.W. 1977, Origin of northwestern Bahama platform: Review and reinterpretation. Geologic Society of America Bulletin, 33: 1447-1461.

Mustoe, G.E. 1982, The origin of honeycomb weathering. Geological Society of America Bulletin, 93: 108-115.

Mylroie, J.E., Carew, J.L. 2008, Field guide to the geology and karst geomorphology of San Salvador Island (Mylroie, J.E., Carew, J.L., Eds.). Bahamian Field Station, San Salvador, 88 p.

Onac, B.P., Sumrall, J., Mylroie, J.E. \& Kearns, J. 2008, Cave minerals of San Salvador Island, Bahamas. The University of South Florida Karst Studies Series, 1, 68 p.

Schneider, J., Torunski, H. 1983, Biokarst on limestone coasts, morphogenesis, and sediment production. Marine Ecology, 4 (1): 45-63.

Taborosi, D., Jenson, J.W. \& Mylroie, J.E. 2004, Karst features in island karst: Guam, Mariana Islands. Zeitschrift für Geomorphologie, 48: 369-389.

Torunski, S.T. 1979, Biological erosion and its significance for the morphogenesis of limestone coasts and for nearshore sedimentation. Senckenbergiana marit, 11: 193-265.

Trudgill, S. (Ed.) 1985, Limestone geomorphology. Longman Publishing, New York, 196 p.

Vacher, H.L. Mylroie, J.E. 2002, Eogenetic karst from the perspective of an equivalent porous medium. Carbonates and Evaporites, 17 (2): 182-196.

Whitaker, F.F., Smart, P.L. 2007, Geochemistry of meteoric diagenesis in carbonate islands of the northern Bahamas: 2. Geochemical modeling and budgeting of diagenesis. Hydrologic Processes, 21: 967-982.

White, B., Curran, H.A. 1988, Mesoscale physical sedimentary structures and trace fossils in Holocene carbonate eolianites from San Salvador Island, Bahamas. Sedimentary Geology, 55: 163-184. 